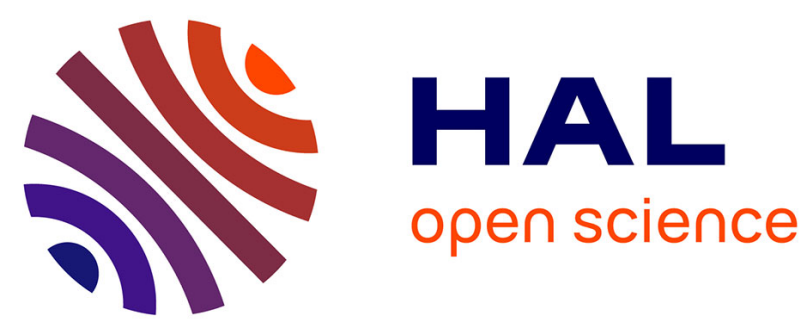

\title{
Complicating the Blame Game: New York Politics, Baseball Fans and the Dodgers' Move Out of Brooklyn Peter Marquis
}

\section{To cite this version:}

Peter Marquis. Complicating the Blame Game: New York Politics, Baseball Fans and the Dodgers' Move Out of Brooklyn. Revue Française d'Etudes Américaines, 2017, 2 (151), pp.206-226. 10.3917/rfea.151.0206 . hal-02061240

HAL Id: hal-02061240

https://hal-normandie-univ.archives-ouvertes.fr/hal-02061240

Submitted on 23 Jul 2019

HAL is a multi-disciplinary open access archive for the deposit and dissemination of scientific research documents, whether they are published or not. The documents may come from teaching and research institutions in France or abroad, or from public or private research centers.
L'archive ouverte pluridisciplinaire HAL, est destinée au dépôt et à la diffusion de documents scientifiques de niveau recherche, publiés ou non, émanant des établissements d'enseignement et de recherche français ou étrangers, des laboratoires publics ou privés. 
Complicating the Blame Game: New York Politics, Baseball Fans and the Dodgers'

Move Out of Brooklyn.

Peter MARQUIS, ERIAC - EA 4705

About sixty years ago, New Yorker music stores sold a recording of comedian Phil Foster's “Keep the Dodgers in Brooklyn” for $\$ 1.25 .{ }^{1}$ Sung in the easily recognizable Brooklyn accent -whereby "thirty three" becomes "dirty tree" - the mock-operatic tune moved from a somber verse to a feet-stomping chorus:

(verse)

Say, did you hear the news about what's happenin' in Brooklyn?

We really got the blues, about what's happenin' in Brooklyn.

It ain't official yet. We hope official it don't get.

But beware my friend and let me warn ya,

they're thinkin' a takin' the Bums to California.

(chorus)

Let's keep the Dodgers in Brooklyn,

a house is not a home without some love.

Don't let them leave our premises,

L.A. would be their nemesis,

'cause Brooklyn fits the Dodgers like a glove.

(verse)

Mister Walter O’Malley, we always called you "pally."

We stuck with you through thick and thin.

\footnotetext{
${ }^{1}$ This article grew from a presentation I gave at the workshop "Popular Culture" at the 2016 AFEA symposium. I would like to thank the organizers as well as the anonymous reviewers at the RFEA and Anaï Bruna for their invaluable feedback.
} 
But if you take away the Dodgers, guys like Campy, Newk and Hodges, we ain't your pal no more the way we been.

(repeat chorus)

Despite the song's melodramatic plea, too little was done to actually "keep the Dodgers in Brooklyn.” In October 1957, Walter O’Malley, president and majority owner of the baseball franchise, announced the relocation to Los Angeles, ending a 74-year long history of reciprocal identity-building in the most populous borough of New York City. Alongside Jackie Robinson's historic breaking of baseball's entrenched color line in 1947 (with the help of Branch Rickey and the communist press), the "move to LA" - as the franchise relocation is often referred to - is one of the best known and most controversial events in baseball history. For a long time, the wellaccepted narrative had contended that Walter O'Malley, a paunchy, ruthless, cigar-smoking businessman broke the heart of millions of humble, die-hard "Flatbush faithful" - mostly working class white ethnics - by uprooting "their" beloved team to the Western Eldorado of TV sponsorships, suburban ballparks, and Disneyland-inspired entertainment. His own justification repeated by most observers since - was the drop in per game attendance and the decrease of the Dodgers' share within the National League. Yet, a closer look at the numbers proves this to be a half-truth: the occupancy rate was still above the team's historical average, as was its share in the National League (Marquis 2009, 336-338). Revenues and profit per spectator per game were also soaring, albeit at a slower pace than in rival cities, like Milwaukee, which had obtained a municipally owned stadium.

Thus, the "blame O’Malley" narrative, however seductive it may be, begs some key questions: how did Dodgers fans - the fabled "Flatbush Faithful" - let their club go so easily? Why was there only a scant mobilization and only in the last months of a decade-long relocation 
debate (1946-1957) $?^{2}$ Is it true that O'Malley had his mind set on leaving many years before the move? What did New York officials do - or failed to do - to help the franchise stay in Brooklyn or the New York area? In other words, was this really the victory of greedy, corporate America over the honest, ticket-paying American fans? In contrast to the accusatory explanations that have up until now dominated the conversation on the Dodgers' move, this article argues that the move rests at a nexus of complex issues pertaining to major shifts in US culture in postwar years. They include alterations of New Deal liberalism, changing models in the consumption of leisure, and evolutions in modes of urban living; all three factors pointing to a redistribution of the roles assigned to the private and public spheres.

The article is based on a reexamination of the existing scholarship as well as an exploration of O'Malley's personal papers, located in the offices of Seidler Partners in Los Angeles. Although the collection is closed to the general public, it was made available to this author on an exceptional basis. ${ }^{3}$ This research also hopes to provide a complete analysis of move-related letters sent to New York Mayor Wagner in 1957, which preceding scholars have noted but touched on only in a cursory fashion. After reviewing the changing interpretations of the team's relocation - mostly a "blame game" - I ponder how the understudied documentation qualifies the consensual narrative. Then, I focus on complicating the grassroots mobilization (or lack thereof) within the changing urban context and the evolution of sports economics. Finally, I consider the "stadium game" (Sullivan, 2001, 163) in regards to the ambivalent position of sports between the public or private spheres.

\footnotetext{
2 The factual history of the move can be divided in four phases; 1946-June 1953: plans to enlarge Ebbets Field; June 1953-Jan. 1954: plans to use Title I money at the Fort Greene site at Flatbush and Atlantic avenues; Aug. 1955-Dec 1956: plans to issue bonds to add a stadium to a redevelopment project at almost the same site; until Oct. 1957: other plans, including Flushing and ultimately Los Angeles.

${ }^{3}$ The staff let me peruse the collection for one day thanks to letters of recommendation and a grant from AFEASAES, to which I am grateful.
} 


\section{Changing interpretations: from accusations to revisions}

Broadly speaking, interpretation of the move falls into three categories, overlapping three periods. First, from the 1960s to the 1990s, there was a vivid anti-O'Malley sentiment, exemplified by one oft-reprinted joke: a man is asked "what would you do if you were facing O'Malley, Hitler, and Stalin and had only two bullets in your firearm?" The sordid answer was, "two in O'Malley's head, to make sure he is dead" (Prince). O'Malley became the arch-villain, the cold hearted, greedy, evil capitalist contemptuous of the fan base that had made him rich. New York-based journalists such as Dick Young, Pete Hamill or Jack Newfield, regularly rehashed the tale of the selfless owner burning the loyalty of millions on the altar of the "almighty buck." Shapiro (24) even dug deep in O'Malley's biography to find that during the Great Depression he had been a "grave dancer" (i.e., a bankruptcy buyer), only to reinforce the notion that he did not care about other people's misery. "Heartbreak," "abandonment," or "trauma," became commonplace vocabulary in mostly anything printed about the move.

In the midst of the 1980s, when Brooklyn was hit by a crisis induced by deindustrialization and ghettoization, the abandonment narrative struck root with former Dodgers fans who had been "broken-hearted" by he move in their youth. By then in their thirties and forties, they kept harboring deep bitterness about the relocation as it dovetailed with the passing of their childhood, often one's happiest times, and the demise of other local institutions, such as the Brooklyn Daily Eagle, or the Navy Yard where many working-class men were employed. Numerous accounts and testimonies focusing on the theme of decline, abandonment and betrayal fill the pages of popular histories of Brooklyn's golden years such as Kahn's best-selling The Boys of Summer (1973), Golenbock's Bums (1984) or Willensky aptly-titled When Brooklyn Was the World (1985). In the meantime, Black and Caribbean families started to move in, as "white flight" took hundreds of thousands of white ethnics to the suburbs. In this economically and 
racially fraught context, O’Malley became "the expiatory victim of modern baseball" (Prince).

The second interpretative framework - which I call revisionist - was led by the pioneering work of public policy professor Neil Sullivan (1987) who introduced Robert Moses, the "power broker" (Caro) of New York politics, into the narrative. Although he was never elected, Moses (1888-1981) is reputed to have had more influence than any mayor of New York: he chaired several key agencies in charge of the city's development in the $20^{\text {th }}$ century, among which the New York City Department of Parks (1934-1960), the Triborough Bridge and Tunnel Authority (1934-1981) and the New York City Planning Commission (1946-1960). He is often credited for being the sole mastermind behind community-shattering infrastructures such as the Cross-Bronx Expressway. Sullivan and others like Shapiro or Ellsworth lay the blame on Moses for never agreeing to O'Malley's plan of building a new stadium near downtown Brooklyn, at the intersection of Atlantic and Pacific avenues, on the site of an old train terminal.

To be specific, the club's president planned to pay for the stadium with his own private money - "I don't want to be a tenant in a political ball park" - but wanted city government to help him with appropriating the land at a reasonable price using federal money from Title I of the 1949 Housing Act. ${ }^{4}$ Part of Truman's Fair Deal, the Housing Act of 1949 was a sweeping urban renewal project expanding the role of Federal government agencies to eliminate "substandard and other inadequate housing through the clearance of slums and blighted areas." To Moses who, as head of the City Committee on Slum Clearance, was in charge of allocating Title I money, there was no ground to grant O’Malley, or any private entrepreneur for that matter, millions' worth of taxpayers' money:

there are other reasons aside from those of law and sound policy why your plan is not one

\footnotetext{
${ }^{4}$ Walter O’Malley to Georges McLaughlin, 18 June 1953; to Robert Moses, October 28, 1953; at the 1957 House hearings (quoted in Sullivan 1987, 127).
} 
that justifies the exercise of the power of eminent domain, not to speak of the use of public funds to reduce the cost of land. Our Slum Clearance committee cannot be used to encourage speculation in baseball enterprises (....).

The anti-Moses camp bases its defense on Robert Caro's portrait of "the czar of New York" as an autocrat who disliked spectator sports (he had been a water polo player and swimmer at Oxford and Yale) and had a vested interest in developing the city outwards to the periphery not in downtown areas. Indeed, in his somewhat elitist view, places of recreation, likes beaches or parks, were be located far from city centers, accessible only by car (running on fee-paying highways) and all had to be under the exclusive control of government authorities which he supervised. Detractors could not resist mentioning that in the 1930s Moses's plans to reform city government had been thwarted by O'Malley's father, a Tammany democrat (McCue, 132). Thus, revisionist interpretations not only challenged the vilification of O'Malley, but introduced another careless villain whose view of urban development entailed a growing exclusion of ordinary folks.

Revealingly, the revisionist interpretation has reached outside of academia: journalists started quoting Sullivan's works and some mainstream media made Moses the major culprit. For instance, in 2006 the leading sports channel ESPN ran a broadcast called "The Top 5 Reasons You Can't Blame Walter O’Malley.” In it, the Irishman's greed disappeared from the narrative, replaced by other factors such as the exodus to the suburbs, the successful relocation of other teams, Los Angeles's enticing offer, and Robert Moses's one-man rule over New York politics. Ironically, anti-Moses revisionism - recently upheld by D'Antonio's 2009 family-approved biography of O'Malley - birthed a new, simplistic dogma ("It's all Moses' fault") which in its turn spawned an anti anti-Moses narrative, either blaming O'Malley first and foremost, or

\footnotetext{
${ }^{5}$ Moses to O’Malley, 22 June 1953, walteromalley.com.
} 
corporate capitalists for dictating public policy priorities.

This third phase began around 2007 and deals with "Revising the Revisionists," to quote from Henry Fetter's award-winning article in New York History. Fetter, an independent researcher and writer for The Atlantic, contends that Moses's staunch opposition merely upheld Title I, that is to say, devoting public money only to public-purpose buildings. In fairness to Moses's detractors, the superintendent had used his powers to clear blocks for a private developer in the Upper West Side (McCue 135) as well as to build the New York Coliseum, whose public purpose seems analogous to that of a baseball stadium. Concerning the Dodgers, however, he demurred. Fetter's greatest merit is to have enlarged the narrative by including Moses within the byzantine power plays between New York politicians and stakeholders, such as mayor Wagner, borough president Cashmore, councilman Stark, but also the fund-allocating Board of Estimates, representatives in Albany, and various business interests. "In conclusion," Fetter writes, "if Robert Moses balked at underwriting O'Malley's agenda, he was not alone. The failure to implement the downtown Brooklyn stadium plan was a collective decision.” (73)

Andy McCue, author of O'Malley's latest biography to date, confirms Fetter's interpretation that neither the team owner nor Moses were to blame - if one wants to be fair - but rather, New York politics as a whole. To put it bluntly, the Dodgers owner would have stayed if New York politicians had let him (xIV). To make his point, McCue makes it clear that the risks O'Malley ran by leaving New York far outweighed the allure of the Californian burgeoning market (155): relocating meant giving up an advertising company that yielded O'Malley higher profits than his baseball business, the lifelong business network he had inherited from his father, and more broadly speaking, the riches of New York City, the world's biggest market for advertising and entertainment (ibid.). Although McCue exposes the club president's cat-andmouse play with the press on whether he considered moving to Los Angeles seriously, the 
historian is adamant that the most reasonable explanation for the move lies in the fact that O’Malley failed to strong-arm Moses and other New York stakeholders into accepting to provide federal money to buy land for a privately owned stadium. McCue concludes by stressing his bewilderment at the lack of mobilization on the part of prominent Brooklyn civic leaders as well as regular Dodgers followers, a topic addressed further in this article.

\section{The O'Malley-Moses correspondence}

Letters from O’Malley's private papers lay bare that O’Malley, when faced with Moses' dogged refusal to use his Title I powers for a private stadium, changed strategy and wooed Brooklyn prominent civic leaders such as Raymond Schroth, owner of the Brooklyn Eagle, the borough's oldest newspaper, to start an awareness campaign for the Dodgers to remain in their home borough. The correspondence suggests that for unclear reasons, Schroth failed to help his longtime ally, but one can hypothesize that the news editor had noticed a drop in sales in Brooklyn whereas they were rising in the neighboring counties of Long Island. This suggested that the fan base had moved out of the borough, making it pointless to build a new stadium where the fans no longer resided, at least in Schroth's reasoning. O'Malley's outreach to other prominent local leaders also yielded few results.

O’Malley probably recognized the exodus to suburbia was irrevocable as he himself had moved his family home from North Brooklyn (780 St. Marks avenue) to Amityville, a Long Island coastal town 55 kilometers from Ebbets Field, the team's ballpark (Shapiro 20). In fact, it seems he was not absolutely averse to Moses' plans of developing New York outward to the suburbs, since his whole rationale for seeking money earmarked for urban renewal was based on his plan to add an underground parking lot at Atlantic and Flatbush to service the stadium. Thus, O’Malley aimed at keeping Brooklyn free of traffic congestion and "commercially attractive for 
employers, shoppers, and strollers" who could commute from their home in Long Island to downtown Brooklyn by using Moses' highways and by parking their cars at the new Dodgers stadium. ${ }^{6}$

The most salient aspect of O'Malley's correspondence lies in his support for the Brooklyn Sports Center Authority (BSCA), a State-approved steering committee controlled by the Board of Estimates and chaired by three prominent local personalities including Chester Allen, president of the Brooklyn Chamber of Commerce and of the Kings County Trust Company. The BSCA was tasked with assessing the feasibility of using Title I money to raze property around the Williamsburg Savings Tower, by Atlantic and Flatbush avenues, and develop new facilities, including a stadium. Contrary to the initial 1954 Fort Greene plan, the BSCA 1956 project suggested that O'Malley would not own the stadium, but rent it to the City, which ran counter to his private enterprise principles but revealed his attachment to New York and its advantages (Sullivan 1987, 72). However, because of tedious bureaucratic procedures and conflicting views - Moses' support for the BSCA was predicated on his hope for a large-scale redevelopment, detached from the building of a stadium (Sullivan 1987, 73) - the BSCA proved ineffectual in raising money to buy any plot of land in downtown Brooklyn for the stadium. In December 1956, O'Malley gave up on the BSCA's earnestness as the only sum it was able to put aside for a preliminary study was a fraction of what had been recommended. In fact, the Board of Estimates, which controlled the BSCA, was chaired by representatives of other boroughs, who saw no reason to favor Brooklyn and worried about the consequences of taking 110 acres of private land off tax revenues. In the meantime, starting in October of the same year, O'Malley had begun discussing the prospect of opening the first major league franchise on the West Coast with Los

\footnotetext{
${ }^{6}$ Walter O'Malley to George McLaughlin, 18 June 1853. Moses suspected O'Malley of hypocrisy, "it is obvious that the garage is financially incidental to the stadium and that the real purpose is to build a new Dodger stadium" (Moses to O’Malley, 2 November 1953).
} 
Angeles officials (McCue, 143).

Throughout 1957 (the move was officially approved by the National League in October), O’Malley remained surprisingly open to public or private suggestions for an affordable plot of land on which he could have his stadium built. At the behest of Moses - who never lost interest in building a city-owned stadium in the far areas of the outer boroughs - O'Malley even considered moving his team to Flushing Meadows on the same site used later for the World Fair or Shea Stadium. The tremor raised by the very name "Queens Dodgers" urged some Brooklynites to mobilize. One of them, Abe Stark, a local businessman who had been associated with the Dodgers for years thanks to an advertising billboard at Ebbets Field ("Hit Sign; Win Suit"), offered to condemn city streets so as to enlarge the stadium. The idea was good electioneering strategy - Stark was also president of the New York City Council and candidate for the borough presidency - but it never materialized (McCue 149). In O’Malley's eyes, Stark then became the archetype of the eleventh-hour patriot, the epitome of New York politicians who pretend to care for their constituents' welfare only when it is in their interest. For example, a March 1957 letter reveals O’Malley's irk at Stark for advocating the construction of a racetrack which, he argued, did not contribute to the welfare of Brooklyn and siphoned taxpayers' money into bad investments.

The Stark proposal is (...) asinine (...); we have every reason to believe that [his] (...) Las Vegas in N.Y. will receive all requisite political support. It will not run into any insufferable delay, divertissement and sabotage that we have encountered. The pari-mutual machine seems to be more attractive to politicians than our sandlot and knothole baseball programs. I am not a prude for the life of me but I cannot see a three million dollar daily pari-mutual handle being good for the morality or 
economics of the community. The politicians have shown beyond a shadow of doubt that they are not with us (...). They have made my decision for me that I would really not want to see any more money wasted for another survey [from the BSCA].

All in all, faced with the failure of negotiations with New York and Brooklyn politicians, O'Malley took the risk of opening a second front of negotiations with Los Angeles officials, but his decision to relocate was never written in stone, at least before late spring 1957.

\section{Dodgers fans mobilize}

In the fall of 1956, when the word was out that the Dodgers might leave Brooklyn to Queens or Los Angeles, some Brooklynites mobilized, albeit tardily and in relatively small numbers: 25,000 signed the "Keep the Dodgers in Brooklyn" petition launched by borough President Cashmore, including 3,500 from Brooklyn College (Gelman). In comparison to the yearly attendance of 1 million paying customers at Ebbets Field, this understandably may have signaled to O'Malley that the "Flatbush Faithful" also had lost hope. A "Keep the Dodgers in Brooklyn Committee" was formed in April 1957, led by Henry Modell, a sportswear retailer who was also co-chairman of the Brooklyn Sports Center Authority. The Committee printed buttons, made announcement on the radio and paid for the recording of Phil Foster's eponymous song.

To today's observer, the committee's actions may look anecdotal: on two pictures taken at rallies in April 1957, there is only a handful of marchers, most of them children ("Keep the Dodgers"). The committee's weaknesses are also visible in the medium and the messages it favored: buttons and posters read "Brooklyn Bum" or "Mr. Moses- don't you dare take the Dodgers to Queens." These words compound what Phil Foster's song revealed: opposition to the

\footnotetext{
${ }^{7}$ Walter O'Malley to Franck Schroth, 26 March 1957, walteromalley.com. The sandlot and knothole baseball programs were Dodgers-funded initiatives providing baseball equipment to Brooklyn and Long Island youth. For a study of their social implications, see Marquis, 2011.
} 
move relied on clichés ("Brooklyn fit the Dodgers like a glove") or sentimentality ("We ain’t your pal no more the way we been"). The idea that baseball owners or city officials would reconsider their position on account of supporters threatening to "stop being pals" seems, in retrospect, somewhat nearsighted.

Another way to probe the grassroots mobilization against the move is through twenty-four letters and two petitions (gathering about 200 signatories) sent by concerned citizens to Mayor Wagner from August 1955 to about March 1957. The first petition was launched by the local branch of B'nai Brith - a Jewish charity - and the other by a collective of Giants and Yankees fans who were concerned about the Dodgers' departure. Nineteen of the letters $(73 \%)$ were sent between February 26 and March 6 when O'Malley announced to the press he had bought property in Los Angeles. The letters deal mostly with pride and economic benefits brought by the team and its fans (33\%), social benefits for community spirit and against juvenile delinquency $(25 \%)$ and political retaliations $(25 \%)$, with letters broaching several of these themes. The larger part insists on the emotional attachment of fans to the team and its history, with a minority calling to mind that the Dodgers serve a social function for the community, while $25 \%$ used ballot blackmail regarding Wagner's bid in the November 1957 mayoral elections. Here is one example, Dear Mayor Wagner:

In Brooklyn we love the DODGERS. Please build the Sports Center here in Brooklyn so we can keep the DODGERS here.

Think! What makes the DODGERS different from other teams? It's the fans and the crazy stunts they pull. The DODGERS are the most colorful team in any league. If you want my vote next election, you will try to get that Sports Center built in 


\section{Brooklyn and fast. ${ }^{8}$}

Many letters argue that the mayor had a civic duty to secure funding from the Board of Estimates because the Dodgers brought in "vast sums of money to the City" in indirect revenues and taxes (the City charged a tax on admissions); besides, municipally owned stadiums in Milwaukee or Kansas City ("inferior cities" to one writer) had generated upward of $\$ 25$ million in additional business, according to one survey. ${ }^{9}$

Interestingly, some took a dimmer view of a municipally built stadium, a plan suggested by the Brooklyn Sports Center Authority:

As a tax payer of the city, as an adult interested in sports and in the health and wealth of our nation, the expenditure of several million dollars [for another baseball park] is a violation of the peoples (sic) confidence (...) The money would be much better spent in the development of playgrounds and in municipal parking areas (...) It is much better to lose face and lose one of our national institutions i.e. "Dodgers" than lose faith with our youth. ${ }^{10}$

This point raises issues - well outside the scope of this article - about the possibility of sportsbased activism in a country where sports franchises are viewed as entertainment companies whose public-purpose comes second, unlike state-funded sports clubs (as is the case in France, for example). Yet, questions beg asking: why did the "Flatbush Faithful" seem to have done so little so late, so to speak, if the stakes were so high? Why did they couch their protest in terms of emotions (one wrote, "[W]ithout [the Dodgers], [t]he summer would certainly be not as enjoyable

\footnotetext{
${ }^{8}$ Frank Russo to Mayor Wagner, 26 February 1957, Wagner Papers. Wagner ended up winning reelection in a landslide with $75.1 \%$ of the vote in Brooklyn, although the turnout was only around $25 \%$ of the total population (the voting-age population for Kings county in 1957 is not available).

${ }^{9}$ Fritz Grimoehl et al. to Mayor Wagner, 23 February 1957; Virginia Hessner to Mayor Wagner, 28 February 1957,Wagner Papers.

${ }^{10}$ Stanley Gross to Mayor Wagner, August 19, 1955, Wagner Papers.
} 
and there would be nothing to look forward to"), ${ }^{11}$ rather than threaten to boycott the Dodgers and the products it advertised, as suggested in Arthur King's corrosive booklet "Dodger Fans of the World, Unite!"?

It is obviously thorny to elaborate on why people do not mobilize, but in my opinion, the lack of mobilization may be construed along three lines: first, Brooklynites did not feel empowered enough to affect the course of "their" team's destiny because the surrounding culture dictated that sports were and should remain apolitical. The almost complete media silence over the political implications of Jackie Robinson's breaking of the color barrier in 1947 bears witness to the dominant notion in the 1940s that sports and politics should not meddle (Sammons). Second, they were cognizant that "their" team, in fact, was not theirs as it belonged to a man whose private interests, in the end, trumped the community's. Third, politically engaged Brooklynites may have been discouraged by the Rapp-Coudert Committee's anti left-wing purges taking place in the 1930s and 40s, notably at Brooklyn College where the Board of Higher Education eventually dismissed 20 faculty members (Lieberman, 287). Finally, Brooklyn-based activism overall waxed and waned: civil rights advocates encountered hardships when attempting to form a Brooklyn chapter of CORE (Congress of Racial Equality) in the early 1950s (Purnell, chapter 2), while Jewish liberalism - spearheaded by Irving M. Levine, leader of the Brownsville Boys Club - declined with the flight to the suburbs (Sorin).

More importantly, I would argue that the move is the consequence of the fans' lack of support, not the cause. So far, few scholars or commentators ventured this way, probably because it was inconvenient to make this point when the majority of old-time fans were still alive. Testimonies found in letters sent to the press and in King's booklet indicate that fans, at least the hundred or so interviewed by King, felt bitter for a series of reasons which he puts down to

\footnotetext{
${ }^{11}$ Carolyn Elardo to Mayor Wagner, February 26, 1957, Wagner Papers.
} 
"mismanagement on the field," "mismanagement off the field," and "poor public relations" (13). On the field, O'Malley's acumen in selecting managers was questioned based on the team's unexpected defeats in 1951, 1952 and 1953; off the field, accounts abound to describe the Dodgers' ticketing services as ineffectual and even humiliating. King recounts how he, as other regulars, tediously went through all the steps to apply for World Series tickets in 1952 only to be told that they were none left; when the author found out on TV that there were empty sections in the stadium, insult was added to injury (9). Other interviewed fans reported a " 100 -foot line at the exchange window," "seats white with pigeon droppings," a pervading smell of urine and spilt beer, a too limited number of 75-cent bleacher seats. In terms of public relations, the rehiring of the official radio announcer, Andre Baruch, "passed [the fans'] understanding" because of his "absurdly bad broadcasts" (13).

Similar negative views were expressed in a series of article by The New York Post in May 1957; for example one man complained, "When I want to treat myself and get a good box seat I can't do it, they've got them sold for the season to some big deals... and half the time they're empty (...) it's just bad business and bad public relations" (Gelman); another bemoaned the bad views or the scarcity of unreserved section seats, which "keeps the kids away" (Gelman); a third one summed it up,

I don't know why I still come here. I guess you have to be nuts. Here they don't give a damn about the fan and the place shows it. I bet there's no more than 8,000 people here and that's more than O'Malley deserves. This guy isn't worried about baseball, to him it's all business (Gelman).

Finally a Dodgers fan based in New Rochelle sent a courteous yet scathing letter of complaint directly to O'Malley in which she describes the whole journey as a nightmare replete 
with "bumper-to-bumper" congestion, "3,000 to 5,000 people trying to push their way to the few windows that were open" with "absolutely no one directing anything," and misattribution of seats. ${ }^{12}$ She intimates that the club's management failed to consider the fans' well-being and finishes with a rhetorical question, "this is the story of my day at Ebbets Field. Tell me, Mr. O'Malley, would you go back?" All in all, it seems that Dodgers regulars felt the club's management neglected the fans, its very lifeline, or at least more than under the previous presidencies of Larry MacPhail (1938-1941) or Branch Rickey (1941-1951). If one is to believe the foregoing, the dropping attendance after the 1955 season may have more to do with the decreasing amount of pleasure fans experienced by going to a game than with their apathy or failing loyalty.

\section{New urbanities}

The defection of fans' support in the run-up to the move should also be contextualized in the broader frame of changes in urban life in the 1940s and 1950s. The real estate revolution taking place in the suburbs drew well-off white ethnics to the periphery of "the old neighborhoods," making real estate available for blacks and Hispanics. "White flight," broadly defined as the move of native-born white city-dwellers to the suburbs to escape the influx of internal colored migrants (Woldoff), was driven by real estate and by racist sentiment as blocks of streets which had been previously all-white became non-white in the course of ten years. Although it was made clear by scholars like Craig Wilder that there was never such a thing as a "racial invasion" of formerly all-white neighborhoods of Brooklyn, the areas of north Brooklyn like Bedford-Stuyvesant or Crown Heights - where Ebbets Field was located - did experience a dramatic influx of minority residents. In these areas, the rate of black occupancy reached $70 \%$,

\footnotetext{
${ }^{12}$ Ira Stanley to O’Malley, 2 August 1956, O’Malley Papers (online).
} 
creating the feeling of racial invasion, while Brooklyn's overall black population grew from $1.4 \%$ to $14 \%$ between 1940 and 1960 (Marquis 2009, 525-530). Yet, stigmatization of these and neighboring areas ensued, paving the way for the 1970s and 1980s ghettoization of once vibrant neighborhoods. However, the real shift in urban demographics at the time was not so much minorities coming in as it was whites getting out. Between 1940 and 1970, the borough of Brooklyn lost about 300,000 white residents, an all-time high deficit (Rosenwaike, 133). The fan base which has supported the Dodgers through WW2 and through Jackie Robinson's breaking the color line in 1947 turned thirty around 1960 and simply did not see a future for itself in Brooklyn anymore. To put it bluntly, the borough changed, hence O'Malley's thought of relocating, not the other way round.

As a matter of fact, O’Malley's willingness to stay and build a new stadium in Brooklyn went against deep-running currents in US urban history. Chief among them was the 1944 "G.I. Bill” which allowed all former WW2 servicemen a scholarship for a four-year college degree and low-interest federal loans to access home ownership (Altschuler \& Blumin). Many Brooklynites, some of whom had served in the military, moved their family and settled in residential suburbs where cookie cutter houses were made affordable by urban engineers like William Levitt, founder of Levittown. Commuting to New York's offices and colleges was facilitated by federally-funded parkways, expressways, bridges and tunnels, whose planning and construction were at Robert Moses's initiative, and part of the 1965 Interstate Highway Act. As suburban sociability differed from old-neighborhood customs - to simplify, life in the suburbs was more private and family-centered while living in the old urban districts valued public outings and community - affiliations and allegiances changed "entail[ing] profound consequences for the design and experience of popular culture after World War II" (Avila, 139). Home television, with 
its emphasis on comfort, personal choice and standardized programming, provides a perfect example of the shift of popular culture to more privatized spaces of leisure. This is suggested by the following quotes from two fans who explained to a New York Post journalist why they stopped going to games at Ebbets Field:

Why knock myself out when all I have to do is have the wife bring out the slippers, tune in the twenty-one-inch screen and relax with some of my favorite brew; The other day I passed right by the ballpark and I was going to go in; then I decided I could enjoy the game on TV (...) and just did that. (quoted in Shapiro, 250).

It seems the postwar turn to a more individualistic culture was echoed in the workplace where allegiances shifted away from group-based identities. The "right-to-work" laws triggered by the 1947 Taft-Hartley Act as well as early deindustrialization caused union membership to plummet, especially in Northern inner cities like Brooklyn (Anersen, 1245). Furthermore, members of the working class - at least those part of the CIO - split into two camps, the liberals and the progressive, mostly left-wingers "whose presence became troublesome in the Cold War era" (ibid.). Additionally, in the late 1930s, former supporters of the New Deal formulated, in Alan Brinkley's words, “a new liberalism (...), less concerned with issues of class, (...) committed above all to a newer version of a consumer-driven economy” (n.p.). For Jonathan Rieder, one of the rare scholars of postwar Brooklyn, this mutation of liberalism bred a backlash among Jews and Italians who reconsidered their support for governmental intervention in social affairs, especially those aiming at racial equity. To a certain extent, consumer-driven liberalism fueled right-wing fears of racial invasion and suspicion of government inefficiency. These postwar changes in urban sociability and political culture may account for the lack of mobilization for the multiracial Brooklyn Dodgers, arguably a symbol of the American democratic promise, much more than O'Malley's greed or New York politicians' reluctance to subsidize professional sports 
teams.

\section{New Sports Economics}

Changes in the economic landscape of sports are also to be taken into account to explain why staying in Brooklyn did not make good economic sense to O’Malley. The 1950s underwent a revolution based on three factors: TV broadcast rights, franchise relocations to cities subsidizing professional sports, and a new sporting creed. For all its existence, Major League baseball had derived its revenues from gate receipts, but in the 1930s, radio broadcasting had started generating new, indirect revenues thanks to broadcast rights paid by channels who sold airtime to advertisers working for manufacturers hoping to boost their product sales. Yet, franchises had remained skeptical, as they feared radio broadcasts would decrease paying attendance. O'Malley was one of the few owners who saw gold in broadcast rights, and he took the reasoning to television. The new medium had made inroads into most American households (by $1960,90 \%$ own a TV set), that is why O'Malley struck a deal to broadcast on TV and radio all the 1955 home games and twenty away games. This earned the franchise around 800,000 dollars in indirect revenues, more than any club except the Giants (Sullivan 1987, 35).

For the 1957 season - the Dodgers' last in Brooklyn - O’Malley bypassed the channels by directly getting revenues from advertisers or manufacturers who would pay to have a billboard set up within the various stadiums O'Malley owned in the minor and major leagues. He also pioneered thoughts about pay-per-view and year-round membership contracts provided by the technological company Skiatron, although elements indicate that the Federal Communication Commission was unfavorable to such developments ("First Customers"). Investing in broadcasting rights, however, ensured O'Malley a wider audience throughout the country and ever-increasing indirect revenues from advertising, rendering the franchise less dependent on 
stadium receipts than other teams. Under such circumstances, staying in the New York area made less business sense than relocating to Los Angeles where pay-TV would be more easily developed, especially because Skiatron would not have to tear up streets to lay cables to customers' houses (McCue 127). Again, this illustrates that the Dodgers' owner told half the truth when citing falling attendance as the basis for a new stadium; the main reason had to do with the scarcity of potential innovation in the New York market, which in a Schumpeterian fashion he viewed as a hindrance to long-term profits.

Even more frustrating for O’Malley was what scholar Neil Sullivan calls the "stadium game" (2001, 163). Starting in 1953 with the Boston Braves' move to Milwaukee, sports franchises in baseball and then in other sports threatened to leave their home cities if the municipalities did not agree to either finance renovation of their existing stadium or pay for a new one. The blackmail was possible given that rising Midwestern or Sun Belt cities - where land was cheap, unlike New York - were willing to promise such public funding in order to "become a major league city." as the phrase goes. Milwaukee had offered Braves' owner Lou Perini to build a stadium with public subsidies which "forged a new relationship between franchises and their stadium" (ibid., 155). The franchise would only have to rent use of the facility while keeping profits for itself and leaving maintenance and repairs to City Hall. In the first nine games of the 1953 season, the Braves garnered more revenues than an entire season in Boston, their previous hometown. The Milwaukee Braves also were the first to break the 2million bar for attendance which, according to O’Malley, "allowed them to offer bigger bonuses to players, manage farm teams and hire the best scouts in the country" (Sullivan 187, 127). In other words, subsidized stadiums introduced unfair competition into baseball.

The Milwaukee example convinced O’Malley that the time had come for franchises to require the support of municipal funding. However, many cities, including NYC where Moses 
had refused to grant Title I status to the Atlantic-Flatbush proposal, balked at the idea of devoting taxpayers' money to such endeavors, partly because of ethics, partly because it was not profitable for a city of New York's caliber. It should be noted that contrary to media assumptions, communities very rarely benefit from publically subsidized stadiums because, as noted sports economists Zimbalist and Noll write, "regardless of whether the unit of analysis is a local neighborhood, city, or an entire metropolitan area, the economic benefits of sports facilities are de minimus."

Third, the sporting economy was shaken by the rise of new allegiances and belief structures, in other words, a new sporting creed. On the one hand, other sports were surpassing baseball in cultural resonance, if not in absolute popularity. College football, for one, drew millions of students and TV viewers every week. Its emphasis on physicality, masculinity, and strategy spoke to the values of veterans and their sons. NCAA basketball also appealed to urban and rural Americans, precisely because of its small-scale atmosphere and often deep ties with the hometown's cultural totems, as exemplified by the Lynds's analysis of Muncie's love affair with the local basketball team (Middletown, 480-485). On the other hand, allegiances changed. The myth that baseball was America's national pastime - orchestrated by the Spalding Commission in 1911 to further cultural nationalism over the British cricket heritage- started eroding on the altar of the new social landscape. First, the Dodgers mystique based on the equivalence between the team's style of play and Brooklynites' working class ethos collapsed as none of the elements in the equation remained valid (Marquis, 206-218); second, if baseball had been America's game, then it was an America stuck in the past, especially regarding the game's complicity with racial segregation. Although Jackie Robinson broke the color barrier in 1947, complete desegregation of America's most popular game took decades, not to mention the personal price players such as Robinson or Larry Doby had to pay for their pioneering role in making American sports 
integrated. $^{13}$

\section{Sports and the public sphere}

In this final part, I would like to suggest a personal interpretation of the move based on appraising the ambivalent place of sports between the private and public spheres. First, as I hoped to demonstrate, fans were not apathetic or spoiled by the consumption of sports on TV, but rather disgruntled by the lack of consideration displayed by Dodgers management and confused by their own ambiguities over whether public money should go to private entertainment businesses. Their testimonies speak to their uneasiness over new standards in popular culture at a time when private leisure took precedence over communal experience. The shift in tastes was induced by technology but also the political will of sports entrepreneurs. Starting in the 1950s, US sports spectacles in stadiums became less by the people, and more for the people. Through heightened orchestration, hyper-commodification, disciplining of the emotions, the sports experience became increasingly framed of the sports experience - as symbolized by the contours of the TV screen highlighting a move from a production-based to a consumer-based society (Marquis, 2016).

Despite the rise of TV, sports entrepreneurs grasped that on-location spectators mattered because empty stands made for poor television. In fact, going further, stadiums may be necessary sites to the production of place, fostering a sense of belonging, and a "we versus us" mentality inherent to sports' metaphorical wars. This explains the ongoing "stadium game" through which franchises blackmail municipalities into building stadiums with taxpayers' money and threaten to relocate to a city with a more generous offer. Not only does it force all citizens, including those

\footnotetext{
13 The many trials Robinson had to go through are recounted in Tygiel's seminal biography The Great Experiment (1983), usefully completed by Lamb's study of the pioneer's first year in the National League (2004); for Larry Doby, the first African-American to integrate the American League (in July 1947 with the Cleveland Indians), see Branson (2016).
} 
indifferent to sports, to subsidize a service they do not use, not only does it deprive schools, hospitals, and - ironically - amateur sports from much-needed funds, but it constitutes inverted welfare, or "stadium welfare" (Sullivan, 2001, 179) whereby the poor are forced by law to give to the rich. These government hand-outs to corporations weaken and corrupt baseball because teams do not have to run a balanced budget, knowing they are too big to fail. Stadium welfare also holds fans hostage: if they do not show loyalty, the team complains about low attendance and relocates, while if they exhibit too much pride in the team, owners play up the team's "public service" role and demand more subsidized aid from municipalities.

To go back to the Dodgers and New York politics of the 1950s, the same stakes, pitting the private and public sectors, lay there in embryonic form. On the one hand, O’Malley - a precursor to contemporary owners - felt he was entitled to public subsidies, as he reckoned that Brooklyn couldn't exist without the Dodgers. ${ }^{14}$ In fact, he took it so much for granted that he wrote to Moses in October 1953,

Incidentally I have not harped on the semi-public nature of a major league franchise nor its importance to a community. I should let our public Borough officials, Chamber of Commerce and others make that presentation. ${ }^{15}$

O'Malley also felt certain that the Yankees' and the Giants' owners, whose teams played against the Dodgers in lucrative cross-town rivalries, would never let politicians squander their business. Yet, the Giants left for San Francisco in 1957, too.

On the other hand, politicians like Moses, Wagner, Cashmore, Stark, or Harriman, exhibited only a perfunctory interest in keeping the Dodgers in Brooklyn. Each had their motives,

\footnotetext{
14 To be specific, "O'Malley asked Moses (...) to use his authority to assemble the package of land (...) for O'Malley's purchase. That would have been the extent of the city's involvement, a one-time exercise of eminent domain rather than a permanent role as landlord" (Sullivan 2001, 115).

${ }^{15}$ Walter O’Malley to Robert Moses, October 28 1957, walteromalley.com.
} 
but I hypothesize that elitism and reformist liberalism played a key role. Moses, for one, made revealing yet equivocal statements about the whimsical character of Brooklynites during a commencement speech he gave in 1955 ,

Brooklyn is a strange borough, (...), an aggregation of three million people, conscious of their identity, nostalgic about the past, sentimental, sensitive to slights, even imaginary ones, (...), fanatically loyal to their baseball team (...) When the Dodgers are on top, it's the morning's morning in Flatbush (...). When the Dodgers are down, there is no joy in Gowanus, (...). What a people! Happy or blue, their disposition depends on the standing of the team (...) If only a fraction of the genuine enthusiasm which the Dodgers arouse could be channeled into the building of a new Brooklyn, what a town it would be! ("Pratt")

It is hard not to detect elitist disdain and scorn for the perceived delusions of ordinary people. Secondly, principles of reformist liberalism seem to have informed the judgments of most politicians involved. They cut their teeth politically during the New Deal era when reformists showed reluctance to government sponsoring of private enterprise. In substance, Moses kept saying in his letters to O'Malley that he held no grudge against baseball or the Dodgers, but he wouldn't use public money for a private endeavor, unless the City were to be the owner of the venue and the team its tenant, which is exactly what it managed to do with Shea Stadium, home of the Mets since 1964. Another option, suggested by Arthur King (29), was for fans to buy out the shares of unfaithful owners and, thus, become part shareholders of the team, in the fashion of today's Spanish socios or German 50+1 (Khan). The drawback is less financial leeway to recruit and develop; the upside is a heightened sense of community, a quandary which evidences that, sixty years after the Dodgers' move out of Brooklyn, sports spectacles still sit uneasily on the fence between private profits and public service. 
Ultimately, this paper argues that the reasons for the Dodgers' move out of Brooklyn are complex and multifactorial. They include O'Malley's refusal to finance the new stadium with his own private funds although he never considered leaving New York until the spring of $1957 ;^{16}$ second, Moses's reluctance to use taxpayers' money to subsidize private businesses, even to help assemble land at under market price; third, the Board of Estimates's fear of political retaliation if it favored Brooklyn over other boroughs; fourth, the BSCA's entanglement in politics and bureaucracy; fifth, changes in leisure and urban culture brought by white flight; sixth, scarce mobilizations against the move. Therefore, not only is it necessary to complicate the blame game, but also to re-contextualize the move within its times.

Postwar America is well-known for ushering in a new way of life based on television, cars, and suburban sociability. James Patterson in his sweeping Great Expectations tidily locates the Dodgers' move within this narrative (315). Although these forces cannot be overestimated, I hold a different view because archival documentation suggests fans did not mind the commute out of Long Island into Brooklyn as much as they resented the Dodgers' management squandering the talent of the team and the good-heartedness of the fans through a series of bad decisions which ended up alienating them.

This might seem anecdotal in the bigger picture of changes taking place in the 1950s but it speaks to what cultural critic John Fiske remarked in 1989, "Popular culture is made by various formations of subordinated or disempowered people out of the resources, both discursive and material that are provided by the social system that disempowers them" (2). Yet Dodgers fans were unable to create a popular culture of resistance because the "social system" (i.e., O'Malley

\footnotetext{
${ }^{16}$ If O'Malley wanted to stay so much, why didn't he indulge and pay the price? McCue provides a psychological portrait of O'Malley as a man, who needed to symbolically kill his towering father, break the mould, leave New York, risk losing it all, and build a monument to his name (356).
} 
and New York politicians) exploited the ambivalent position of sports between the private and the public spheres. On the one hand, O’Malley claimed the business of baseball was too private to be transferred to government authority, on the other, elected officials reckoned the service it rendered to the community was too precious to be trusted to entrepreneurs. Confused and stranded with no team to root for, metaphorically, Dodgers fans voted with their feet, watched games from home and blamed O'Malley, whereas what took "their" team away lay in the demise of reformist liberalism, heightened privatization in the consumption of leisure, and growing subsidization of sports teams outside of New York. What was happening within the old, smelly grandstands of Ebbets Field between 1946 and 1957 was a microcosm of broader changes in American culture and both a catalyst and a buttress for these very mutations. 


\section{Works Cited}

"First Customers for Pay Television," Life, 14 October 1957, 68.

"Keep the Dodgers in Brooklyn," music by Roy Ross, words by Sam Denoff and Bill Persky, sung by Phil Foster, Coral Records, New York, 1957, available at http://ow.ly/lQt3308beZK.

"Keep the Dodgers in Brooklyn Committee" folder, Brooklyn Collection, Brooklyn Public Library.

"Pratt, in Graduating 290; Hears Moses on the Dodgers," New York Herald Tribune, 4 June 1955, completed by a copy of the speech at Brooklyn College, Special Collections Room.

“Top Five Reasons You Can't Blame Walter O'Malley for the Dodgers Leaving Brooklyn," ESPN Classic, original airdate: May 30, 2006.

Arnesen, Eric. Encyclopedia of U.S. Labor and Working-Class History. Vol. 1, New York: Routledge, 2007.

Altschuler, Glenn C, and Stuart M. Blumin. The G.I. Bill: A New Deal for Veterans. Oxford U P, 2009.

Avila, Eric, Popular Culture in the Age of White Flight. Fear and Fantasy in Suburban Los Angeles, U of California P, 2004.

Branson, Douglas M. Greatness in the Shadows: Larry Doby and the Integration of the American League. Lincoln: U of Nebraska P, 2016.

Brinkley, Alan. The End of Reform New Deal Liberalism in Recession and War. New York: Vintage Books, 1996.

Caro, Robert. The Power Broker: Robert Moses and the Fall of New York, New York, Knopf, 1974. 
D’Antonio, Michael. Forever Blue: The True Story of Walter O'Malley. New York: Riverhead Books, 2009.

Fetter, Henry D., “Revising the Revisionists: Walter O’Malley, Robert Moses and the End of the Brooklyn Dodgers.” New York History, vol. 89, 55-74 (2008).

Fiske, John. Reading the Popular. Boston: Unwin Hyman, 1989.

Gelman, David, "Will the Dodgers Go West ?,” New York Post, fourth article in a series, 24 May 1957.

Golenbock, Peter. Bums: an Oral History of the Brooklyn Dodgers, New York, Putnam, 1984.

Khan, Roger. The Boys of Summer, Signet Classics, Harper \& Row, 1971.

Khan, Khalid, "Cure or Curse: Socio Club Ownerships in Spanish La Liga," Bleacher Report, 2010 (online), consulted 14 May 2017.

King, Arthur. Dodger Fans of the World, Unite!: Is This the Truth About Baseball Today? New York: William Frederick Press, 1957.

Lamb, Chris. Blackout: The Untold Story of Jackie Robinson's First Spring Training. U of Nebraska P, 2004.

Liebermann, Robbie, "Shooting Rabid Dogs: New York's Rapp Coudet Attack on Teachers Unions," in Goldstein, Robert J., ed. Little "Red Scares": Anti-communism and Political Repression in the United States, 1921-1946, Routledge, 2016, 287-314.

Lynd, Robert Staughton, and Helen Merrell Lynd. Middletown, A Study in Contemporary American Culture. New York: Harcourt, Brace and Company, 1929.

Marquis, Peter. 'Brooklyn et 'ses' Dodgers. Baseball et construction des identités urbaines aux Etats-Unis (1883-1957)." PhD. diss., history, EHESS, 2009, available on HAL at http://ow.ly/89v3308boIy (French).

Marquis, Peter, "Penser base-ball. Formes et enjeux de l'action caritative des Dodgers de 
Brooklyn en faveur de la jeunesse locale (1913-1957)," Transatlantica [online], 2 (2011).

Marquis, Peter. "Taking Elias "Out to the Ball Game." Baseball Spectatorship and the "Quest for Excitement" in American Sports Festivities," Revue française d'études américaines, vol. 146, no. 1, pp. 54-67 (2016).

McCue, Andy. Mover and Shaker: Walter O'Malley, the Dodgers, and Baseball's Westward Expansion. U of Nebraska P, 2014.

Patterson, James T. Grand Expectations: Postwar America, 1945-1974. New York: Oxford UP 1995.

Prince, Carl, conversation with the author, Dec. 5, 2005

Purnell, Brian. Fighting Jim Crow in the County of Kings: The Congress of Racial Equality in Brooklyn, U P of Kentucky, 2015.

Rieder, Jonathan. Canarsie: The Jews and Italians of Brooklyn against Liberalism. Harvard U P, 1985.

Rosenwaike, Ira. Population of New York City, Syracuse U P, 1972.

Sammons, William, "Jackie Robinson and the American Mind: Journalistic Perceptions of the Reintegration of Baseball," Journal of Sport History, vol. 12, n¹, p. 39-64 (1985).

Shapiro, Michael. The Last Good Season: Brooklyn, the Dodgers, and Their Final Pennant Race Together, New York, Doubleday, 2003.

Sullivan, Neil. The Diamond in the Bronx, Oxford U P, 2001.

Sullivan, Neil. The Dodgers Move West, Oxford U P, 1987.

Sorin, Gerald, "Brownsville and Irving Levine. The Making of a Jewish Liberal Activist," in Abramovitch, Ilana, ed., Jews of Brooklyn, New York, Brandeis U P, 2002.

Wagner Papers, Brooklyn Sports Center (3), 1957, roll 8, box 15, folder 176, Archives of the City of New York. 
Wilder, Craig S. A Covenant with Color: Race and Social Power in Brooklyn, New York, Columbia U P, 2000 [1994].

Willensky, Elliott. When Brooklyn Was the World, 1920-1957, New York, Harmony Books, 1986.

Woldoff, Rachael A. White Flight/Black Flight: The Dynamics of Racial Change in an American Neighborhood. Ithaca: Cornell U P, 2011.

Zimbalist, Andrew and Roger G. Noll, "Sports, Jobs, \& Taxes: Are New Stadiums Worth the Cost?" The Brookings Institution [online], 1997. 